\title{
Improving the Business Production of Sumedang Tofu Through Equipment Provision and Business Assistance
}

\section{Peningkatan Produksi Usaha Tahu Sumedang Melalui Penyediaan Peralatan dan Pendampingan Usaha}

\author{
Marlya Fatira AK ${ }^{\mathrm{a}, *}$, S. Suadi ${ }^{\mathrm{b}}$, Eli Safrida ${ }^{\mathrm{a}}$, Rihat Sebayang ${ }^{\mathrm{b}}$, N. Nurlinda ${ }^{\mathrm{a}}$ \\ ${ }^{a}$ Jurusan Akuntansi, Politeknik Negeri Medan, Indonesia \\ ${ }^{b}$ Jurusan Teknik Mesin, Politeknik Negeri Medan, Indonesia
}

\begin{abstract}
This article about efforts to increase the production of Sumedang Tofu as the small and micro business through the Supply of Equipment and Business Assistance. This programs do to increase the production of Sumedang tofu according to market needs. This programs expected that business owners understand how to make simple financial statements, understands about healthy and safe ways to dispose of business waste, able to see business opportunities from the management of business waste know for fut ure business development, Provide brand signs to introduce business to the wider community. The method used in this community service program is collecting data/information about prospective partners through surveys and interviews. The information is analyzed descriptively, implemented and carried out an evaluation of the community service program as a whole to see compliance with the output target. The results show that the customer order service is able to be produced with tofu grinding machines with a capacity of $50 \mathrm{~kg} / \mathrm{hour}$, limited production equipment can be overcome with the engine the problem of recording business financial statements has now been able to be separated and carried out in accordance with the material that was submitted during the training for recording simple financial statements.
\end{abstract}

\begin{abstract}
Abstrak
Artikel ini membahas tentang upaya peningkatan produksi tahu sumedang sebagai Usaha Kecil dan Mikro (UKM) melalui penyediaan alat dan bantuan usaha. Program ini dilakukan untuk meningkatkan produksi tahu Sumedang sesuai kebutuhan pasar. Melalui program ini diharapkan para pelaku usaha memahami bagaimana membuat laporan keuangan yang sederhana, memahami tentang cara-cara yang sehat dan aman untuk membuang sampah usaha, mampu melihat peluang usaha dari pengelolaan sampah usaha tahu untuk pengembangan usaha kedepannya, Memberikan rambu merek untuk memperkenalkan usaha kepada masyarakat luas. Metode yang digunakan dalam program pengabdian masyarakat ini adalah pengumpulan data / informasi tentang calon mitra melalui survei dan wawancara. Informasi tersebut dianalisis secara deskriptif, dilaksanakan dan dilakukan evaluasi program pengabdian kepada masyarakat secara keseluruhan untuk melihat kesesuaian dengan target keluaran. Hasil penelitian menunjukkan bahwa customer order service mampu diproduksi dengan mesin gerinda tahu berkapasitas $50 \mathrm{~kg} / \mathrm{jam}$, terbatasnya alat produksi dapat diatasi dengan mesin permasalahan pencatatan laporan keuangan usaha kini sudah dapat dipisahkan dan dilaksanakan sesuai dengan materi yang disampaikan selama pelatihan pencatatan laporan keuangan sederhana.
\end{abstract}

(C) 2020 Author(s)

Keywords: Sumedang Tofu, Small Business, Equipment, Accompaniment

* Corresponding author:
E-mail address: marlyafatira@polmed.ac.id (Marlya Fatira AK)

Mattawang: Jurnal Pengabdian Masyarakat is licensed under an

Attribution-NonCommercial-ShareAlike 4.0 International (CC BY-NC-SA 4.0) 
https://doi.org/10.35877/454RI.mattawang207

\section{Pendahuluan}

Tahu merupakan makanan yang terbuat dari bahan dasar kedelai yang difermentasikan dan diambil sarinya. Tahu sebenarnya bersal dari negara Cina diartikan sebagai kata serapan yang berasal dari bahasa Hokain (Tauhu) (Hanzi: Hanyu piyin: Doufu) yang memiliki arti kedelai yang difermentasikan. Pertama kali tahu muncul di negara Tiongkok ketika zaman dinasti Han tepatnya 2200 tahun lalu. Di Indonesia tahu sangat populer, dan sangat digemari oleh setiap lapisan masyarakat. Tahu oleh masyarakat Indonesia sering dikonsumsi sehari-hari. Makanan ini dapat dibuat berbagai jenis camilan, salah satunya cemilan tahu sumedang. Usaha Pembuatan Tahu di Indonesia senantiasa menjanjikan prospek usaha yang sangat baik, karena tahu memang sangat sering dikonsumsi oleh masyarakat indonesia. Hal ini disebabkan karena tahu memiliki kandungan protein yang sangat tinggi sehingga sangat baik untuk kesehatan tubuh, dipercaya dapat mengurangi risiko penyakit cancer, selain itu dapat menjaga kesehatan kulit serta menyehatkan darah.

Besarnya Prospek Usaha Pembuatan tahu di Indonesia khususnya di Kota Medan, menjadikan salah satu keputusan dasar yang menyebabkan Bapak Danu Mulyadi memberanikan diri untuk membuka usaha pembuatan Tahu di tempat tinggalnya. Usaha pembuatan tahu sumedang milik Bapak Danu Mulyadi telah dimulai sejak bulan Januari 2016, saat ini usia usahanya telah berjalan kurang lebih 6 bulan. Usaha Pembuatan Tahu sumedang Danu berada di Jalan Cinta Karya Gang Pante Kelurahan Sari Rejo Kecamatan Medan Polonia Kota Medan. Kegiatan Pembuatan Usaha pembuatan tahu Bapak Danu setiap harinya dimulai dari pukul 8.00 wib s.d. selesai pesanan. Setiap harinya untuk memproduksi tahu dibutuhkan sebanyak $150 \mathrm{~kg}$ kedelai untuk diproduksi. Kedelai akan diolah untuk menjadi Tahu Sumedang kemudian akan diolah menjadi 84 papan tahu siap jual. Dalam 1 papan tahu terdiri dari 100-120 potong tahu, yang dihargai untuk harga Rp1000,00 per 3 potong tahu. Untuk 1 papan tahu memiliki nilai jual Rp21.000,00.

Selama ini kegiatan produksi dilakukan setiap hari, termasuk hari libur, dalam satu bulan libur produksi hanya dilakukan 2 hari. Dengan kegiatan kerja selama 28 hari dalam satu bulan, usaha pembuatan tahu sumedang milik bapak danu mampu menghasilkan omset usaha Rp1.764.000,00 setelah dipotong biaya produksi diperoleh pendapatan bersih kurang lebih Rp200.000-300.000 per harinya, sehingga dalam satu bulan usaha tahu ini mampu memberikan penghasilan bersih kurang lebih Rp4.000.000-Rp9.000.000,00. Sampai saat ini yang menjadi biaya produksi yang harus difikirkan oleh bapak Danu adalah:

Tabel 1 Rincian Biaya Produksi

\begin{tabular}{|c|c|c|}
\hline Rincian Biaya & Satuan $(\mathrm{Rp})$ & Jumlah (Rp) \\
\hline Kayu Bakar & $700.000 /$ minggu & 2.800 .000 \\
\hline Listrik dan Air & $150.000 /$ bulan & 150.000 \\
\hline Minyak Solar & $100.000 /$ minggu & 400.000 \\
\hline Gaji Karyawan & $\begin{array}{l}70.000 / \text { hari (penuh) } \\
50.000 / \text { setengah hari }\end{array}$ & 3.360 .000 \\
\hline Jumlah Total Pengeluaran & & $\operatorname{Rp} 6.710 .000$ \\
\hline
\end{tabular}

Proses pembuatan tahu sumedang ini adalah sebagai berikut:

1) Kedelai yang akan diproses terlebih dahulu di rendam selama 2 jam pada wadah ember plastik hitam yang telah disediakan, setelah didiamkan 2 jam, dan kulit kedelai sudah mengelupas maka proses dapat dilanjutkan.

2) Kedelai yang telah mengelupas kulitnya dicuci dan dimasukkan kedalam mesin penggiling kedelai, secara bertahap sesuai kemampuan mesin untuk berproduksi.

3) Setelah kedelai halus, maka hasilnya dimasukkan didalam kuali besar untuk direbus dengan air selama 15 menit.

4) Kedelai yang telah halus dimasukkan dalam ayakan yang terbuat dari kain paris dengan pori-pori sangat halus. (kain ayakan ini setiap 2 hari sekali akan dicuci dan diganti dengan kain ayakan lainnya). 
5) Setelah kedelai diayak, maka proses berikutnya kedelai yang telah halus dimasukkan dalam tong besar untuk dicampur dengan air cuka. Adonan kedelai tersebut diaduk sampai rata, kemudian didiamkan selama 10 menit, selanjutnya air rendaman dibuang, dan tahu diletakkan pada papan cetakan tahu yang terbuat dari kayu, diamkan 15 menit, telah menjadi tahu dan kemudian siap untuk diangkat dan dipotong untuk kemudian dimasukkan ke dalam tong kemasan penjuakan tahu yang berwarna biru.

\section{Permasalahan Mitra}

Berdasarkan hasil survei dan wawancara yang dilakukan dengan Bapak Danu Mulyadi sebagai pemilik dan pengelola Usaha Pembuatan Tahu Sumedang, diketahui beberapa masalah yang dihadapinya selama mengelola usaha, yaitu:

a) Produksi Tahu sedikit dan Pesanan Pelanggan Tidak Terpenuhi

Bapak Danu tidak mampu memenuhi seluruh pesanan pelanggan karena kemampuan produksi pada mesin penggiling yang dimilikinya saat ini masih terbatas. Saat ini Bapak Danu hanya memiliki satu buah Mesin untuk penggiling kedelai. Mesin tersebut berkapasitas kecil sehingga kemampuan menggiling kedelai sedikit, rata-rata kemampuan mesin untuk satu kali proses penggilingan adalah $12 \mathrm{~kg}$ kedelai, lama proses penggilingan untuk 1 kali proses adalah 30 menit. Hal ini menjadikan proses pembuatan tahu menghabiskan waktu 6 jam 25 menit pada proses penggilingan saja.

b) Peralatan Produksi sangat terbatas

Peralatan Produksi yang dimiliki oleh Bapak Danu sampai saat ini masih terbatas sekali, bapak Danu memulai usahanya berusaha dengan memakai barang bekas, dan hasil pinjaman, serta ada beberapa barang yang masih dalam proses cicilan kredit. Beberapa alat produksi yang dimiliki usaha tahu bapak Danu adalah:

Tabel 2 Aset Usaha Tahu Bapak Danu Mulyadi

\begin{tabular}{|c|c|c|c|}
\hline No & Uraian Aset & Jumlah & Keterangan \\
\hline 1 & $\begin{array}{l}\text { Mesin Penggiling } \\
\text { Produksi } 12 \mathrm{Kg}\end{array}$ & 1 & Milik pribadi (kondisi sering rusak) \\
\hline 2 & Wadah Cetakan Tahu & 5 & Milik pribadi \\
\hline 3 & Drum Tempat Penmapung Air & 1 & Milik pribadi \\
\hline 4 & Ember untuk menempatkan Tahu & 10 & $\begin{array}{l}5 \text { milik pribadi } \\
5 \text { pinjaman milik pelanggan }\end{array}$ \\
\hline 5 & Kain kasa untuk mengayak & 2 & Milik pribadi \\
\hline 6 & Ember Hitam pengangkat air & 4 & Milik pribadi \\
\hline 7 & Ember Hitam besar untuk merendam tahu & 3 & Milik pribadi \\
\hline 8 & Kuali besar dari Baja & 1 & Milik pribadi \\
\hline 9 & Tempat usaha & 1 & Sewa, Milik Mertua \\
\hline
\end{tabular}

Sumber: Hasil wawancara dengan Pemilik Usaha Tahu Danu Mulyadi, Juni 2016

Usaha Pembuatan Tahu Milik Bapak Danu memiliki potensi yang besar untuk berkembang jika menggunakan peralatan yang lebih modern dengan kemampuan produksi lebih banyak, sehingga pesanan dapat dikerjakan lebih cepat. Hal ini dapat dilihat dari pesanan yang diterima bukan saja dari masyarakat sekitar tetapi juga dari pabrik tahu, rumah makan, dan perhotelan yang ada di Kota Medan.

c) Banyak Limbah Tahu yang Terbuang

Dari proses pengolahan bahan baku menjadi kedelai ternyata banyak sekali limbah yang hasilkan, dan sampai dengan saat limah tahu terbut setaip harinya banyak terbuang, adapun limbah tahu tersebut berbentuk:

(1) Ampas kedelai, sisa dari kedelai yang telah dihaluskan

Saat ini ampas kedelai yang dihasilkan dari produksi tahu setiap harinya mencapai 3-4 goni besar ukuran 30 $\mathrm{kg}$, khusus untuk ampas kedelai dapat memberikan manfaat bagi para peternak kambing, lembu dan babi 
yang ada di daerah sekitar kota medan. Setiap harinya para peternak tersebut datang ke usaha pak Danu untuk membeli ampas kedelai guna diberikan kepada ternak mereka. Harga 1 goni ampas kedelai dihargai Rp25000. Sehingga ampas kedelai setiap harinya selalu habis disalurkan tidak ada yang terbuang menjadi sampah.

(2) Air rebusan kedelai yang tidak terpakai, sampai saat ini air tahu sisa rebusan kedalai banyak sekali yang terbuag. Rata-rata setiap harinya ada sebanyak 36 tong air 100 liter air tersebut dibuang keselokan. Terkadang ada beberapa mahasiswa dari pertanian USU datang ke usaha pembuatan tahu danu untuk meminta sedikit limbah air tahu yang akan digunakan sebagai bahan praktik di kampus. Limbah air tahu ini perlu dimanfaatkan kedepannya, sehingga lebih bernilai guna bagi usaha pabrikan dan masyarkat sekitar usaha pembuatan tahu.

Masalah pengelolaan limbah usaha tahu merupakan masalah yang rutin dihadapi para pengelola usaha industri tahu, limbah ini memberikan pengaruh yang sangat besar terhadap kebersihan lingkungan dan sangat berdampak negatif untuk kesehatan manusia, karena itu perlu dilakukan penangnan tertentu untuk terhadap limbah tahu ini. Pada umumnya limbah tahu terdiri dari dua jenis limbah yaitu limbah cair dan limbah padat. Limbah cair sebenarnya bisa dimanfaatkan sebagai biogas yang bisa dimanfaatkan untuk pengganti bahan bakar. Sednagkan untuk limbah padat bisa dimanfaatkan untuk menjadi nata decoco, tepung, kerupuk atau pakan ternak.

d) Usaha Pembuatan Tahu Belum Memiliki Izin Usaha

Usaha Pembuatan Tahu milik Bapak Danu Mulyadi ini belum memiliki izin usaha dari industri rumahan. Sehingga hasil produksi tahunya penjualannya masih sangat terbatas, dan umumnya para pelanggan yang langsung datang untuk membeli tahu produksinya. Saat ini Pak Danu masih berangapan belum perlu untuk mengurus izin usaha tahunya karena kemampuan produksi masih terbatas bahkan kebutuhan pelangganpun belum mampu dipenuhi seluruhnya.

e) Pencatatan hasil usaha Tahu belum dipisahkan, masih dicampur dengan penggunaan kebutuhan keuangan keluarga.

Berdasarkan hasil wawancara yang dilakukan Tim PPM Polmed diketahui bahwa, pengelolaan keuangan usaha pembuatan tahu milik bapak Danu belum dilakukan dengan baik, sampai saat ini usaha tahu bapak Danu belum memiliki pencatatan kegiatan usahanya, mereka terbiasa mencampur pendapatan dari hasil usaha pembuatan tahu dengan kebutuhan harian rumah tangga, hal ini kadang menjadi kesulitan saat menghitung berapa keuntungan usaha, biaya karyawan serta berbagai biaya yang harus disediakan untuk modal pengembangan usaha kedepannya.

\section{Solusi yang Ditawarkan}

\subsection{Solusi yang ditawarkan}

Memperhatikan berbagai pemasalahan yang dihadapi Usaha Pembuatan Tahu Sumedang Bapak Danu yang telah diuraikan sebelumnya, maka tim PPM Polmed hadir untuk memberi solusi atas permasalahan tersebut dan mengupayakan untuk memberikan solusi atas masalah yang menjadi prioritas utama untuk diselesaikan terlebih dahulu sesuai dengan rencana kegiatan yang akan dilakukan:

a) Bidang Produksi

Solusi yang ditawarkan tim PPM untuk bidang produksi adalah:

1. Memberikan Mesin Penggiling Kedelai dengan Kapasitas besar $50 \mathrm{~kg}$ per jam.

2. Memberikan Peralatan Produksi berupa Drum air, dan Ember sebagai wadah tahu

b) Bidang Manajemen

Pada bidang manajemen solusi yang ditawarkan Tim PPM adalah:

1. Pelatihan Pembuatan Laporan Keuangan Sederhana untuk Usaha Pembuatan Tahu

2. Pemberian Informasi dalam bentuk pemaparan mengenai cara sehat dan aman untuk membuang limbah usaha tahu.

3. Pemberian Informasi dalam bentuk pemaparan mengenai peluang usaha pengelolaan limbah usaha tahu untuk pengembangan usaha kedepannya. 
c) Bidang Pemasaran

Memberikan Plang Usaha Pembuatan Tahu Danu Mulyadi sebagai identitas usaha sebagai bentuk strategi pemasaran agar usaha dikenal masyarakat sekitar, akan dilakukan pada tahap berikutnya.

\subsection{Target Luaran}

Target Luaran yang diharapkan pada program PPM Usaha Pembuatan Tahu Sumedang Melalui Inovasi Mesin Penggiling Kedelai sesuai dengan solusi yang ditawarkan sebagai berikut:

a) Bidang Produksi

Target luaran yang diharapkan tim PPM untuk bidang produksi adalah:

Penambahan aset Usaha Tahu Milik Bapak Danu Mulyadi berupa Mesin Penggiling kedelai, Drum Air, dan Ember sebagai wadah tahu

b) Bidang Manajemen

Pada bidang manajemen solusi yang ditawarkan tim PPM berupa:

1. Pengelolaan Usaha Tahu Milik Bapak Danu Mulyadi memiliki Laporan keuangan Keuangan Sederhana untuk Usaha Pembuatan Tahu

2. Diketahuinya Informasi mengenai cara sehat dan aman untuk membuang limbah usaha tahu.

3. Diketahuinya Informasi mengenai peluang usaha pengelolaan limbah usaha tahu untuk pengembangan usaha kedepannya.

c) Bidang Pemasaran

Adanya Plang Usaha Pembuatan Tahu Danu Mulyadi sebagai identitas usaha sebagai bentuk strategi pemasaran agar usaha dikenal masyarakat sekitar, hal ini akan dilakukan pada tahap berikutnya.

\section{Metode Pelaksanaan}

Program PPM ini dilakukan dengan mengumpulkan data deskriptif dan kualitatif yang kemudian dianalisis dan diproses guna menghasilkan solusi bagi Usaha Pembuatan Tahu Sumedang Melalui Inovasi Mesin Penggiling Kedelai di Keluarahan Sari Rejo Kecamatan Medan Polonia Kota Medan, yaitu berupa Memberikan Mesin Penggiling Kedelai dengan Kapasitas besar 50 kg per jam, Memberikan Peralatan Produksi berupa Drum air, dan Ember sebagai wadah tahu, memberikan pelatihan Pembuatan Laporan Keuangan Sederhana untuk Usaha Pembuatan Tahu, pemberian Informasi dalam bentuk pemaparan mengenai cara sehat dan aman untuk membuang limbah usaha tahu, Pemberian Informasi dalam bentuk pemaparan mengenai peluang usaha pengelolaan limbah usaha tahu untuk pengembangan usaha kedepannya, serta memberikan Plang Usaha Pembuatan Tahu Danu Mulyadi sebagai identitas usaha sebagai bentuk strategi pemasaran agar usaha dikenal masyarakat sekitar.

Dalam Pelaksanaan PPM ini digunakan metode sebagai berikut:

a. Teknik Pengumpulan Data

Pengumpulan data dilakukan melalui wawancara kepada pemilik usaha tahu bapak Mulyadi, sertanya Ibu Nining guna mengumpulkan informasi berupa:

- Profil usaha Tahu milik Bapak Danu Mulyadi

- Permasalahan-permasalahan yang dihadapi usaha Tahu milik Bapak Danu Mulyadi

b. Teknik Analisa Data

- Analisis Deskriftif

- Mendesain materi pelatihan pencatatan laporan keuangan sederhana untuk usaha tahu

- Pelatihan dan implementasi pencatatan laporan keuangan sederhana untuk usaha tahu

- Mendesain bentuk informasi yang akan disampaikan cara sehat dan aman untuk membuang limbah usaha tahu,

- Serta mendesain bentuk Informasi mengenai peluang usaha pengelolaan limbah usaha tahu cair dan padat untuk pengembangan usaha kedepannya

- Kunjungan 2 bulan (2 kali kunjungan) setelah implementasi dan pelatihan serta evaluasi dampak teknik kepada usaha tahu Bapak Danu Mulyadi. 
Kegiatan PPM ini diawali dengan melakukan kunjungan ke lokasi mitra, kemudian melakukan wawancara dengan mitra yang diwakili langsung oleh pemilik usaha pembuatan tahu Bapak Danu Mulyadi serta Istri Ibu Nining sebagai pengelola Keuangan Usaha Tahu. Setelah semua informasi tentang mitra diperoleh maka dilakukanlah diskusi atas perencanaan solusi atas permasalahan yang dihapi mitra, diikuti dengan implementasi dan sosialisasi serta validasi terhadap solusi yang ditawarkan Tim PPM.

Dalam pelaksanaan program PPM ini, mitra juga dilibatkan untuk berperan secara aktif sebagai peserta dalam pelatihan, pelaksanaan pengelolaan manajemen usaha pembuatan tahu. Mitra mengundang pekerja usaha tahu dan masayarakat sekitar serta menyediakan tempat untuk pelaksanaan sosialisasi kegiatan. Setelah kegiatan dilakukan maka Tim PPM akan melakukan evaluasi terhadap program yang telah dilakukan. Selain itu setelah implementasi program, tim PPM juga tetap melakukan kunjungan sebagai keberlanjutan program setelah selesai kegiatan PPM di lapangan.

\section{Hasil dan Pembahasan}

Program Pengabdian Masyarakat dengan judul PPM Usaha Pembuatan Tahu Sumedang di Kelurahan Sari Rejo Kecamatan Medan Polonia yang diusulkan merupakan hasil kolaborasi multi disiplin ilmu yaitu teknik mesin, akuntansi, dan manajemen keuangan syariah. Hal ini sesuai dengan kurikulum pendidikan dan pengajaran di POLMED dan bidang keahlian pengusul, serta relevan dengan rencana pengabdian/pengalaman pada masyarakat yang dilakukan oleh tim pengusul.

Adapun personalia pelaksana kegiatan program Pengabdian bagi Masyarakat dan untuk memperlancar proses pelaksanaan kegiatan pengabdian tim pengusul juga akan dibantu oleh 2 orang mahasiswa terdiri dari 1 program studi D3 Teknik Konversi Energi dan 1 Program studi D4 Akuntansi sektor Publik. Dengan rincian sebagai berikut:

a. Membantu sebagai bagian administrasi: 1 orang mahasiswa

b. Membantu sebagai bagian lapangan: 1 orang mahasiswa

Berdasarkan latar belakang pendidikan dan pengalaman yang ada, maka tim pengusul merasa layak dan mampu untuk melaksanakan kegiatan pengabdian dengan topik yang diusulkan. Tim pengusul juga telah menyusun modul pelatihan yang akan dilampirkan pada proposal ini, beserta dengan profil khalayak sasaran.

Memperhatikan tahapan pelaksanaan kegiatan pengabdian masyarakat yang telah direncanakan sebelumnya maka dilakukanlah kegiatan pengabdian. Kegiatan Pengabdian masyarakat dilakukan di kediaman rumah mitra yaitu Bapak Danu. Dalam kegiatan tersebut diberikan alat produksi yang dibutuhkan mitra berupa satu unit mesin Penggiling kedelai serta diberikan pelatihan penggunaan operasional mesin disertai perawatan mesin penggiling kedelai, pemberian pelatihan penyusunan laporan keuangan sederhana oleh Narasumber kepada Pak Danu, Ibu Nining dan beberapa pengusaha kecil di sekitar lingkungan tempat tinggal pak Danu dan Bu Nining. Bapak Danu juga diberikan pelatihan tentang strategi pengembangan usaha, melalalui inovasi pada jenis variasi limbah tahu untuk diolah menjadi beberapa produk yang bernilai tinggi, pemberian label merek dagang serta memperoleh ijin usaha untuk industri rumah tangga. Hadir dalam kegiatan ini sebanyak 10 orang terdiri dari karyawan Bapak Danu, beserta 5 orang pemilik usaha kecil yang berada di Kelurahan Cinta Rakyat, Jalan Cinta Karya Kelurahan Sari Rejo Kecamatan Medan Polonia Kota Medan. Hasil yang diperoleh dari kegiatan pengabdian ini adalah: Melalui kegiatan pengabdian kepada masyarakat menghasilkan keberhasilan mitra mengatasi masalah yang dihadapinya, yaitu Pak Danu kini telah mampu mencatatkan laporan keuangan usaha nya dengan akuntansi sederhana, mengerti mencatat dalam buku kas, buku persediaan, buku piutang serta mampu menentukan harga pokok pembelian dan penentuan keuntungan usaha. Usaha tahu sumedang kini telah mampu meningkatkan hasil produksinya $80 \%$ lebih banyak dari produksi awal sejak menggunakan mesin penggiling kedelai. Stategi pengelolaan usaha yang dilakukan oleh Pak Danu juga semakin baik dengan mampu mengolah limbah air tahu menjadi bermanfaat dan bernilai jualpemberian label merek dagang dan pendaftaran ijin usaha serta kini usaha tahu sumedang Danu semakin mampu memenuhi kebutuhan pemesan terutama hotel dan rumah makan disekitar kota Medan. 


\section{Simpulan dan Saran}

\subsection{Simpulan}

1. Produksi Tahu sedikit dan Pesanan Pelanggan Tidak Terpenuhi

Sebelum pelaksanaan PPM usha tahu Bapak Danu tidak mampu memenuhi seluruh pesanan pelanggan karena kemampuan produksi pada mesin penggiling yang dimilikinya masih terbatas, setelah PPM dan memperoleh mesin dengan kapasitas produksi $50 \mathrm{~kg} / \mathrm{jam}$ maka produksi meningkat dua kali lipat dengan waktu yang lebih singkat 50\% sehingga permasalahn ini menjadi terselesaikan.

2. Peralatan Produksi sangat terbatas

Sebelum kegiatan PPM Peralatan Produksi yang dimiliki oleh Bapak Danu masih terbatas namun setelah dilaksanakan PPM, usaha pembuatan tahu bapak Danu mendapatkan tambahan mesin untuk produksi sehingga berangsur angsur dari keuntungan usahanya perlatan produksi yang dibutuhkan bisa ditambah hal ini dengan adanya bantuan dari tim PPM Polmed. Keadaan ini menunjukkan Permasalahn pada peralatan telah dapat diatasi $50 \%$ dengan adanya bantuan dari Tim PPM.

3. Pencatatan Hasil usaha tahu kini telah dilakukan dengan benar sesuai dengan pencatatan akuntansi keuangan sederhadan untuk usaha kecil yang telah diajarakn oleh Tim PPM Polmed. Hal ini menunjukkan pelaksanaan PPM untuk pelatihan pencatatan keuangan sederhana bagi usaha kecil yang diberikan oleh Tim PPM berhasil diterapkan menyelesaikan solusi.

\subsection{Saran}

1. Diharapkan setelah pelaksanaan kegiatan pengabdian, pengusaha tahu tetap melakukan proses pencatatn laporan keuangan secara disiplin sehingga dapat bermanfaat saat ia membutuhkan modal tambahan dari stakeholder nantinya.

2. Diharapkan plang merek usaha pembuatan tahu serta izin usaha tahu dapat diurus sehingga pemasaran produk menjadi lebih baik dan lebih terpercaya.

\section{Acknowledgements}

Ucapan terima kasih tim pengabdian ucapkan kepada Direktur Politeknik Negeri Medan dan Jajarannya yang telah mendanai program pengabdian masyarakat ini melalui DIPA Politeknik Negeri Medan, serta tim ucapkan terimakasih UPPM Polmed, serta kepada mitra pengabdian Pak Danu dan Ibu Nining, serta masyarakat di Kelurahan Cinta Rakyat.

\section{References}

Bahri, Nisfan, R. Sebayang, M. Fatira AK. 2019. Strategi Pengembangan Usaha Susu Kedelai Di Desa Mekar Sawit Kecamatan Sawit Seberang Kabupaten Langkat. Prosiding Seminar Nasional Pengabdian Masyarakat SENIAS 2019. Kediri: Institut Ilmu Kesehatan Bhakti Wiyata.

Huraerah, Abu. 2008. Pengorganisasian dan Pengembangan Masyarakat. Bandung: Humaniora

Jessy Adack. 2013. Dampak Pencemaran Limbah pabrik tahu terhadap lingkungan Jurnal Lex Administartum, Vol.I/No.3?Jul-Sept/2013.unsrat.ac.id

Suharto, Edi. 2009. Kemiskinan dan Perlindungan Sosial di Indonesia. Bandung: Alfabeta

Widiastuti, M. 2013.Pengaruh Limbah Industri Tahu terhadap Kualitas Air Sungai di Kabupaten Klaten. Jurnal Bumi Indonesia. Universitas Gajah Mada.

http://www.tokomesin.com/peluang-usaha-industri-tahu-dan-analisa-usahanya.html, diunduh 10 Juni 2016 
Fatira, et.al| Mattawang: Jurnal Pengabdian Masyarakat, 2020, 1(2): 71-78

http://www.tipemesin.com, diunduh 20 Mei 2016

http://www.bhineka.com, diunduh 20 Mei 2016

http://www.beritametro.co.id/gresik/nata-de-soya-dari-limbah-tahu, diunduh 10 Juni 2016

http://www.tubasmedia.com/biogas-dihasilkan-dari-limbah-air-tahu/, diunduh 10 Juni 2016 